\title{
THE ORIGINS OF AFRICAN-AMERICAN FAMILY STRUCTURE*
}

\author{
StEVEn Ruggles \\ University of Minnesota
}

\begin{abstract}
I use a new data source, the Integrated Public Use Microdata Series, to trace race differences in family structure between 1880 and 1980. Analysis confirms recent findings that the high incidence among African-Americans of single parenthood and children residing without their parents is not a recent phenomenon. From 1880 through 1960, black children were two to three times more likely to reside without one or both parents than were white children. In recent years, however, the race differential in parental absence has grown. Also, blacks have had a consistently higher percentage of extended households than have whites, but until 1940 this was the result of single parenthood and parentlessness among children: Extended households were more common among whites once the effects of absent parents were controlled.
\end{abstract}

$\mathrm{T}$ wo distinctive features of African-American family structure are well known: Blacks are far more likely than whites to become single parents and to reside in extended families. The theories offered to explain these differences are diverse and have generated heated debates. I attempt here to narrow the field of potential explanations for race differences in family structure by presenting a concise and detailed description of changes in black family structure from 1880 to 1980 .

Since the turn of the century, social theorists have argued that slavery resulted in disorganization and instability in black families (DuBois 1899, 1909; Elkins 1963; Frazier 1932, 1939; Myrdal 1944). This interpretation culminated with Moynihan's (1965) report, which concluded that the "pathological" nature of black communities could be traced to the deterioration of black family life.

The numerous arguments against the Moynihan report can be divided into two broad cat-

* Direct correspondence to Steven Ruggles, Department of History, 267 19th Avenue South, University of Minnesota, Minneapolis, MN 55455; internet: RUGGLEs@ATLAS.SOCSCI.UMN.EDU. Funding for data preparation was provided by the National Science Foundation (SES-9118299 and SES9210903), the National Institute of Child Health and Human Development (HD 25839), and the Graduate School of the University of Minnesota. This research was carried out under a Bush Sabbatical fellowship from the University of Minnesota. My thanks to Robert McCaa, Stuart Tolnay, and the anonymous $A S R$ reviewers for their helpful comments and suggestions. egories. Many theorists have argued that Moynihan got it backwards: The disadvantaged position of blacks is not the consequence of single-parent families, but rather the cause of them. This interpretation is frequently accompanied by the thesis that the black extended family has been a means of coping with both poverty and single parenthood (Allen 1979; Billingsley 1968; Farley 1971; Fischer, Beasley, and Harber 1968; Hofferth 1984; Rainwater and Yancey 1967; Stack 1974). Other theorists have maintained that Moynihan's stress on pathology and disorganization ignores the resilience of the black family, and especially the strength of extended kin ties among blacks (Aschenbrenner 1973; Hays and Mindel 1973; Hill 1971; Martin and Martin 1978; McAdoo 1980; Riessman 1966; Staples 1975). These analysts often point to persistent cultural differences between whites and blacks-originating in slavery or in African culture-to explain both single parenthood and extended family structure (Nobles 1978; Owens 1976; Scanzoni 1971; Shimkin, Shimkin, and Frate 1978).

The controversy over the Moynihan report stimulated a spate of revisionist historical investigations into African-American family structure. These studies asserted that black families in the late nineteenth century were overwhelmingly male-headed and nuclear in structure. Although some authors acknowledged minor differences in family structure between blacks and whites, they all maintained that in practical terms black families were essentially similar to white families (Agresti 1978; Bigham 1981; Carlson 1988; Fursten- 
berg, Hershberg, and Modell 1975; Gutman 1975, 1976; Harris 1976; Krech 1982; Lammermeir 1973; Pleck 1972; Riley 1975; Shifflett 1975). The revisionists thus implied that the distinctive African-American family pattern is of recent origin, and this reinforced the now widespread view that economic disadvantages faced by blacks in the recent past are responsible (Brewer 1988; Wilson 1987).

A more recent group of historical studies has revised the revisionists' conclusion. These investigations have stressed the continuity of African-American family structure by showing that the high frequency of single-parent families among blacks observed by Moynihan in 1965 already existed around the turn of the century (Brown and Kallgren 1989; Goeken 1989; Gordon and McLanahan 1991; Morgan, McDaniel, Miller, and Preston 1993; Ruggles and Goeken 1992). These studies have made it clear, therefore, that the current African-American family pattern was not a response to recent economic changes. To explain the distinctive features of the African-American family, we need to look back at least as far as the nineteenth century.

My investigation builds on the recent historical research. I describe for the first time the long-term trends of single parenthood and extended family structure among blacks and whites, using a new series of census microdata that spans the period from 1880 to 1980 . The recent historical studies have shown that single parenthood and extended families were more common among blacks than among whites at the turn of the century, but they have not been able to trace these changes over the course of the twentieth century.

\section{DATA}

Until recently, historians lacked adequate data to trace long-term national trends in family structure. With few exceptions, empirical analyses of race differences in historical family structure have focused on a single moment in time. Moreover, the bulk of historical studies have examined living arrangements in one or two communities. We have had no way of determining if the communities are representative, and comparisons between studies have been complicated by variations in data sources, data collection procedures, and classifications of family structure. The most recent historical studies of African-American family structure have used national census data from the turn of the century, but even they have not yielded statistics that are directly comparable to data available for the recent past.

Now, a new data source, the Integrated Public Use Microdata Series (IPUMS), allows us to generate for the first time a consistent national series of statistics on family structure over the past century (Ruggles et al. forthcoming). The IPUMS is a national historical census database in preparation at the University of Minnesota under funding from the National Science Foundation and the National Institutes of Health. The IPUMS combines national census microdata from a variety of sources. Since 1960, the U.S. Census Bureau has made public use microdata samples available to researchers within a few years of the decennial enumeration (U.S. Bureau of the Census 1972, 1973, 1982). Since 1979 , projects carried out at the University of Minnesota, the University of Washington, the University of Pennsylvania, and the University of Wisconsin have converted large national samples of the 1880 , $1900,1910,1940$, and 1950 population censuses into machine readable form (Graham 1979; Ruggles et al. 1993; Strong et al. 1989; U.S. Bureau of the Census 1984a, 1984b). Similar projects are now underway at Minnesota for the 1850 and 1920 census years. Altogether, large samples of census microdata are anticipated for at least 11 census years between 1850 and 1990.

These census files employ a wide variety of sampling strategies, sample units, and coding schemes. The IPUMS imposes a consistent set of definitions and codes on the data, establishing order and maximizing the potential for valid and reliable analysis of long-term change (Ruggles 1991, forthcoming b). When complete, the IPUMS will include national samples of coherent census microdata from all census years for which data are available. I used the preliminary version of the database in this analysis; it includes census data from 1850 , $1880,1910,1940,1960$, and $1980 .^{1}$

\footnotetext{
${ }^{1}$ The IPUMS is scheduled to be released in the summer of 1995 through both the National Archives and the Inter-University Consortium for Political and Social Research. A preliminary version of the data series is available from the author. For descriptons of the source data, see text citations. The sample densities used throughout this study
} 
Table 1. Percentage Distribution of Household Composition by Race: United States 1880-1980

\begin{tabular}{|c|c|c|c|c|c|c|c|c|c|c|}
\hline & \multicolumn{5}{|c|}{ Black } & \multicolumn{5}{|c|}{ White } \\
\hline & 1880 & 1910 & 1940 & 1960 & 1980 & 1880 & 1910 & 1940 & 1960 & 1980 \\
\hline \multicolumn{11}{|l|}{ Fragmentary Households } \\
\hline Primary individuals & 8.5 & 10.5 & 15.4 & 17.6 & 26.7 & 5.0 & 6.2 & 9.5 & 14.6 & 26.7 \\
\hline Single parents & 11.7 & 9.7 & 8.7 & 9.9 & 20.5 & 8.2 & 7.4 & 7.1 & 5.1 & 7.1 \\
\hline Total fragmentary & 20.3 & 20.2 & 24.1 & 27.5 & 47.2 & 13.2 & 13.6 & 16.6 & 19.7 & 33.9 \\
\hline \multicolumn{11}{|l|}{ Married Couple Households } \\
\hline Childless couples & 11.6 & 16.9 & 19.6 & 16.0 & 10.6 & 11.0 & 14.5 & 20.5 & 23.2 & 24.7 \\
\hline Couples with children & 45.6 & 38.5 & 29.8 & 31.1 & 25.1 & 56.4 & 51.9 & 45.6 & 45.6 & 34.9 \\
\hline Total married couple & 57.3 & 55.4 & 49.4 & 47.1 & 35.6 & 67.3 & 66.5 & 66.0 & 68.8 & 59.6 \\
\hline \multicolumn{11}{|l|}{ Extended Households } \\
\hline Vertically extended & 13.1 & 14.1 & 16.6 & 14.1 & 10.1 & 10.7 & 10.9 & 11.0 & 6.9 & 3.9 \\
\hline Other extended & 9.4 & 10.3 & 9.9 & 11.3 & 7.0 & 8.8 & 9.0 & 6.4 & 4.6 & 2.6 \\
\hline Total extended & 22.5 & 24.4 & 26.5 & 25.4 & 17.2 & 19.5 & 19.9 & 17.4 & 11.5 & 6.6 \\
\hline Total percent & 100.0 & 100.0 & 100.0 & 100.0 & 100.0 & 100.0 & 100.0 & 100.0 & 100.0 & 100.0 \\
\hline Number of households & 12,449 & 8,616 & 6,276 & 4,789 & 8,387 & 84,398 & 70,375 & 62,678 & 47,8796 & 69,024 \\
\hline $\begin{array}{l}\text { Index of dissimilarity } \\
\text { (Black-white, } \\
\text { six categories) }\end{array}$ & 10.7 & 13.4 & 16.7 & 21.7 & 24.0 & & & & & \\
\hline
\end{tabular}

Note: Excludes group quarters under 1970 Census definition. Primary individuals are persons heading households with no kin present; single parents are unmarried heads with children and no other kin; childless couples are married couple households with no kin; couples with children are married couples with children and no other kin; extended households are households with kin other than spouse and children; vertically extended are households with ancestors, descendants, or children-in-law of head.

Despite the problems of compatibility introduced by their compilers, the U.S. Public Use Microdata Samples (PUMS) currently constitute the most consistent and comprehensive source available for the study of long-term change in family and household composition. From 1850 onwards, the census definitions of the basic units of enumeration-now called households-have varied only modestly, and the proportion of units affected by such variations has been insignificant. The concepts of quasi-household and group quarters, introduced since 1940, have no clear analogs in earlier censuses, but the PUMS files for all years provide sufficient information to impose a lowest common denominator of the group quarters concept. Moreover, the basic inquiries required to classify household and family composition-relationship to household head or house-

were $1 / 200$ for $1850,1 / 100$ for $1880,1 / 250$ for $1910,1 / 500$ for 1940 , and $1 / 1000$ for the remaining years. holder, marital status, age, and sex-are virtually identical for all available census years since $1880 .^{2}$

\section{LONG-TERM TRENDS IN HOUSEHOLD COMPOSITION}

Table 1 provides a general description of household composition by race from 1880 to 1980 . The classification scheme is a compromise be-

${ }^{2}$ For discussions of the temporal comparability of the census concepts of family and household, see Ruggles (1991) and Smith (1992). The definition of group quarters used here is the one used for the 1970 Census; that definition is the only on that can be applied consistently across all census years from 1880 to 1980 . For the sake of consistency, persons residing in group quarters under 1970 Census definitions were excluded from analysis in this study, except for Table 3 and for the statistics from the 1850 Census. On the potential effects of this exclusion, see Ruggles $(1988,1991)$. 
tween the U.S. Census Bureau approach to household structure and the system developed by Laslett (1972) that is widely used by historians. Households are divided into three broad categories on the basis of the composition of the primary family, which is defined as the group of kin related to the household head. ${ }^{3}$ Fragmentary households consist of primary individuals and single parents residing with their children only. Married couple households include married couples residing with no other kin and married couples residing with their children and no other kin. Extended households include additional kin, such as parents, siblings, or grandchildren of the household head. Vertically extended households are those that include ancestors, descendants, or children-in-law of the household head.

Among both blacks and whites, the most striking change in household structure shown in Table 1 is the increase in the percentage of primary individual households-persons who reside alone or with nonrelatives only. In the nineteenth century, blacks resided as primary individuals significantly more often than whites, but by 1980 this race difference had disappeared. The dramatic rise of the primary individual over the past century has generated a large literature (see for example Kobrin 1976; Ruggles 1988).

For this analysis, the most important categories in Table 1 are single-parent households and extended households. Among blacks, the percentage of single-parent households was relatively stable from 1880 through 1960 , and then it increased sharply. The percentage of extended households among blacks was also fairly stable between 1880 and 1960, but has dropped significantly since then.

In all census years, a smaller percentage of white households were fragmentary or extended than were black households, and they more often consisted of married couples residing with children. These race differences increased between 1880 and 1980 . The key categories of black household structure, however,-single-parent and extended-were re-

${ }^{3}$ These systems are described in U.S. Bureau of the Census (1983) and in Laslett (1972). Following U.S. Census Bureau practice, the term family refers here to any group of related people who reside together, whereas the term household refers to a group of people who share living quarters, regardless of their relationships. markably stable, at least through 1960 . This finding supports the recent studies arguing that the distinctive features of the African-American family have deep historical roots.

Despite this long-standing continuity, the race differential in household composition has not been static. In Table 1 the index of dissimilarity compares the distributions of black households and white households across the six detailed categories. From 1880 through 1980, divergence between black and white household composition increased-the index of dissimilarity rose gradually from 10.7 to 24.0. Thus, although the origins of the characteristic patterns of black household composition can be traced to the nineteenth century, race differences have become far more pronounced over the course of the twentieth century.

\section{THE LIVING ARRANGEMENTS OF CHILDREN}

Measurement by households minimizes race differences in family structure. We can obtain a clearer view by focusing on the living arrangements of children. There are several advantages to analyzing children living with single parents instead of single-parent households. To begin with, we can broaden the analysis by looking at children who resided with no parents as well as children who resided with a single parent. Moreover, by measuring the living arrangements of children, we can easily capture single parents who were not household heads and who resided in subfamilies and secondary families. Furthermore this measurement strategy greatly simplifies analysis of measurement error resulting from demographic change. ${ }^{4}$ Finally, children are an important object of study in their own right, and are key to understanding the family as an agent of socialization.

Table 2 shows the percentage of children residing with both parents, with mothers only, with fathers only, and without either parent. The overall percentage of children with one or both parents absent is summarized in Figure 1.

\footnotetext{
${ }^{4}$ For technical reasons, it is extremely difficult to account for the effects of demographic factors on living arrangements when measurements are taken at the level of households (see Ruggles 1986, 1987).
} 


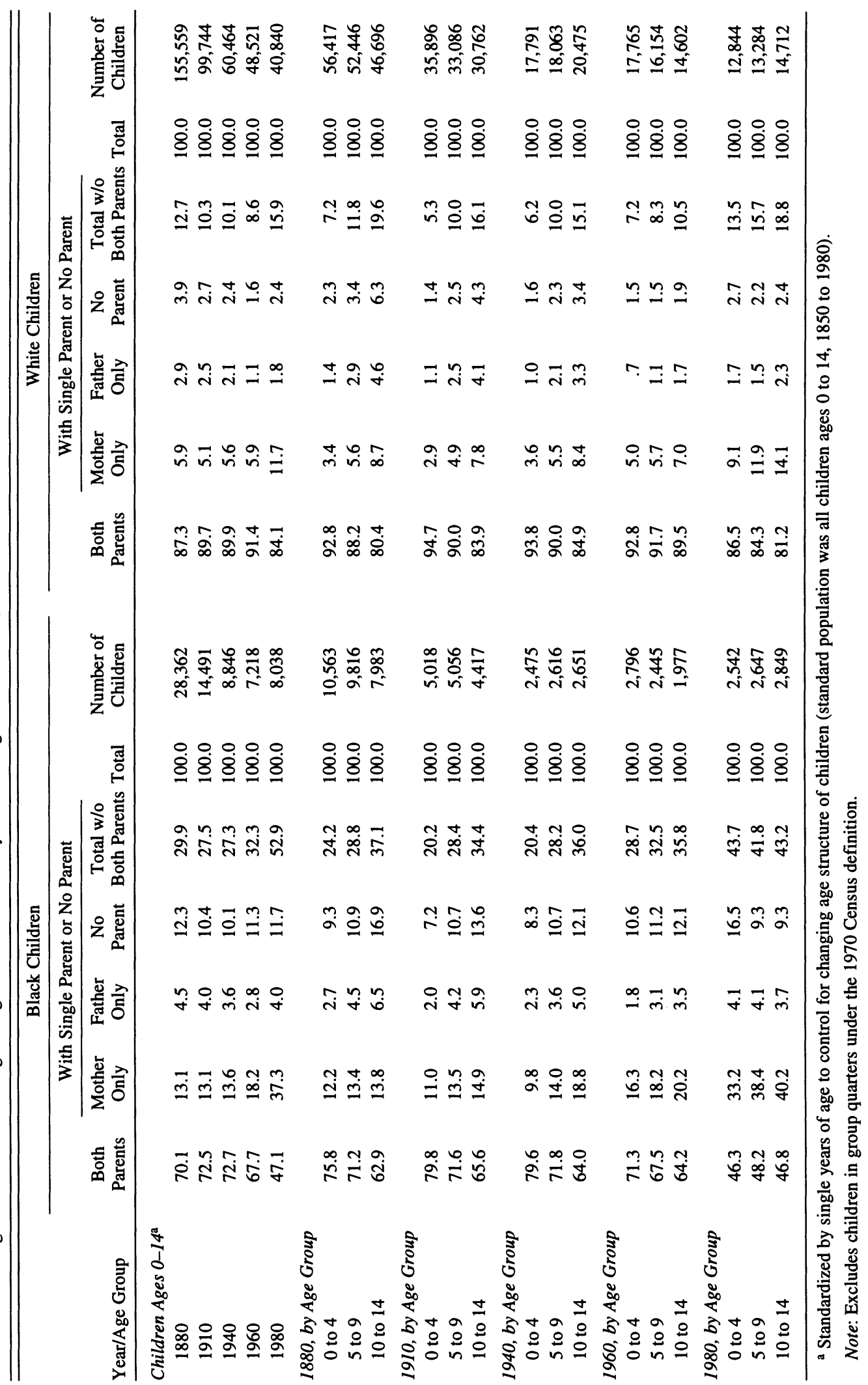




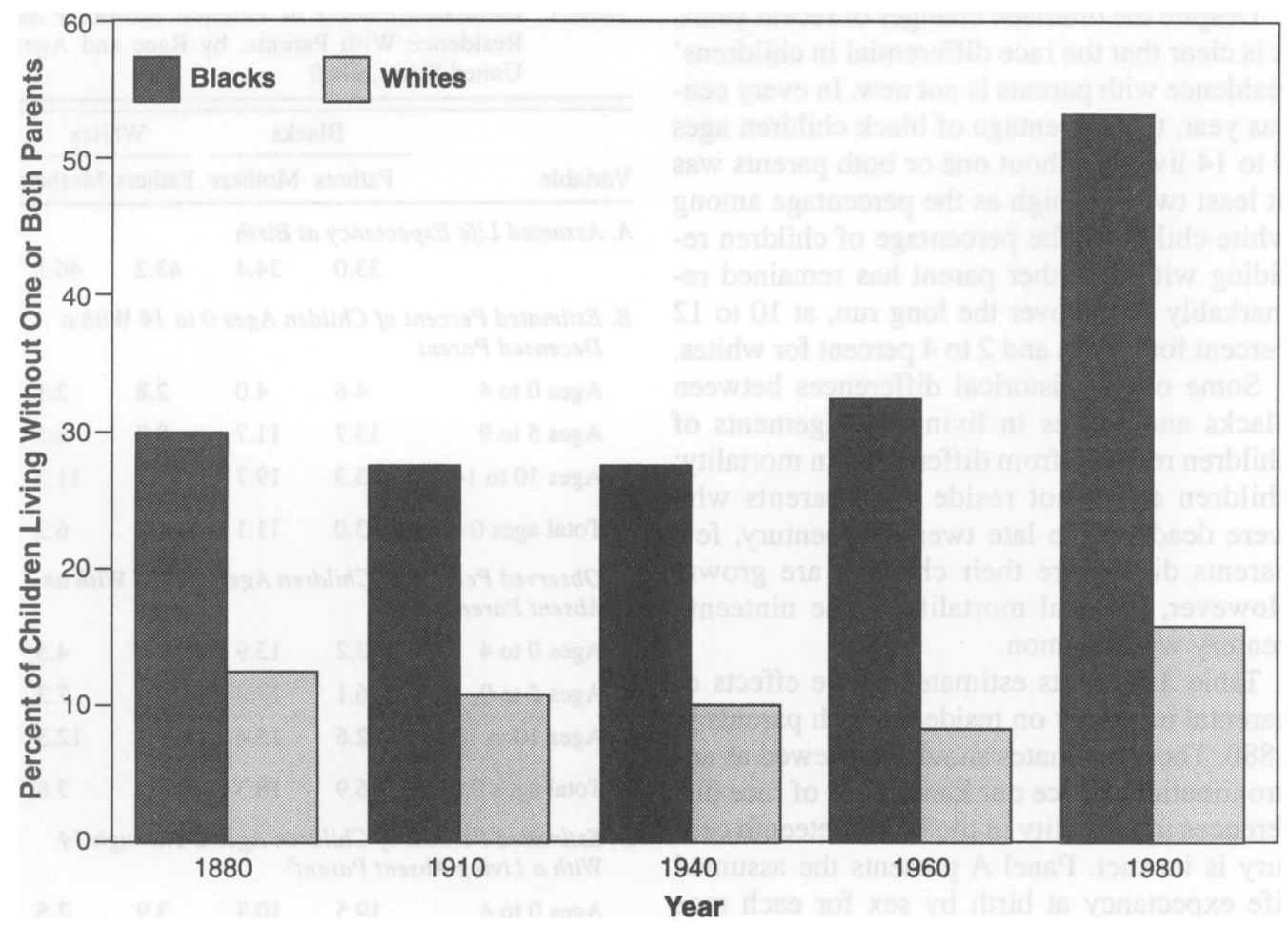

Figure 1. Percentages of Children Ages 0 to 14 With One or Both Parents Absent, by Race: United States, 1880-1980

The presence of parents was determined from information available consistently from 1880 to 1990: relationship to head, age, sex, marital status, and sequence within the household. ${ }^{5}$ From 1880 through 1960, about 30 percent of black children ages 0 to 14 resided without one or both parents. By contrast, only about 10 percent of white children resided without one or both parents over the same years. From 1960 to 1980 , parentlessness and single parenthood rose sharply among both blacks and whites. The rate of change for whites was somewhat

${ }^{5}$ In the great majority of cases, the determination of the parent-child link was based entirely on family relationship and age. Occasionally, there was more than one potential mother or father for a given child; in such circumstances, the choice between alternate parents was based on marital status, if possible, or proximity within the household if not. Detailed programming instructions for the linking procedure appear in Ruggles et al. (1993). The percentage of children reported in Table 2 as residing without mothers in the 1910 census year is slightly different from the figures reported in Morgan et al. (1993). This is because the IPUMS uses a different procedure to link parents and children than that used in the 1910 project. The 1910 project used greater over those two decades than it was for blacks: The percentage of white children residing without both parents rose 85 percent, compared with only a 64 percent increase among black children. Measured as an absolute percentage, however, the recent change has been far greater among blacks, because they started from a higher base percentage. Parental absence among black children rose from 32 percent in 1960 to 53 percent in 1980, while among white children the increase was from 9 percent to 16 percent over the same period.

some additional variables which more consistently identified step-children and adopted children (i.e., surname, detailed relationship categories, number of children surviving, number of children ever born, parental birthplaces, marriage age, and duration of marriage). Since this additional information is not available across all census years, it could not be used to construct a consistent set of parent-child links. Accordingly, the linking procedure used was more likely than that used for the $\mathbf{1 9 1 0}$ study to assign parenthood to a few people who are actually step-parents or foster parents. Any such errors, however, should be consistent across all census years studied. 
Despite the dramatic changes of recent years, it is clear that the race differential in childrens' residence with parents is not new. In every census year, the percentage of black children ages 0 to 14 living without one or both parents was at least twice as high as the percentage among white children. The percentage of children residing without either parent has remained remarkably stable over the long run, at 10 to 12 percent for blacks and 2 to 4 percent for whites.

Some of the historical differences between blacks and whites in living arrangements of children resulted from differences in mortality; children could not reside with parents who were dead. In the late twentieth century, few parents die before their children are grown. However, parental mortality in the ninteenth century was common.

Table 3 presents estimates of the effects of parental mortality on residence with parents in 1880. These estimates should be viewed as approximations, since our knowledge of race differences in mortality in the late nineteenth century is inexact. Panel A presents the assumed life expectancy at birth by sex for each race based on life tables for the period from 1870 to 1880. Panel B shows the percentage of fathers and the percentage of mothers who would be dead for each age group of children under these mortality conditions. Panel $\mathrm{C}$ shows the percentage of children with absent fathers and absent mothers. These figures are similar to those in Table 2, but they include children who were residents of group quarters. ${ }^{6}$ Panel D of Table 3 estimates the percentage of children with a surviving parent who is absent, calculated from panels $\mathrm{B}$ and $\mathrm{C}$. The percentages of children with a living absent parent may be slightly understated, because panel $\mathrm{C}$ includes some unknown percentage of adopted and step-children residing with socially-defined parents whose biological parents were dead. ${ }^{7}$

${ }^{6}$ Figures in Panel $\mathrm{C}$ differ from the figures presented in Table 2 because Panel $\mathrm{C}$ includes children residing in group quarters; unlike later census years, the 1880 sample allows full identification of family relationships for persons in group quarters. Since children residing in group quarters were especially likely to have deceased parents, they must be included for comparison with the parental mortality estimates.

7 I used a simple life table approach to measure parental survival, which involved calculating the probability of death for each parent from the birth
Table 3. Estimated Effects of Parental Mortality on Residence With Parents, by Race and Age: United States, 1880

\begin{tabular}{|c|c|c|c|}
\hline \multirow[b]{2}{*}{ Variable } & \multicolumn{2}{|c|}{ Blacks } & Whites \\
\hline & Fathers & Mothers & Fathers Mothers \\
\hline
\end{tabular}

B. Estimated Percent of Childen Ages 0 to 14 With a Deceased Parent

$\begin{array}{lrrrr}\text { Ages } 0 \text { to } 4 & 4.6 & 4.0 & 2.8 & 2.1 \\ \text { Ages } 5 \text { to } 9 & 13.7 & 11.7 & 8.8 & 6.5 \\ \text { Ages } 10 \text { to } 14 & 23.3 & 19.7 & 15.7 & 11.3 \\ \text { Total ages } 0 \text { to } 14 & 13.0 & 11.1 & 8.7 & 6.3\end{array}$

C. Observed Percent of Children Ages 0 to 14 With an Absent Parent ${ }^{\mathrm{a}}$

$\begin{array}{lrrrr}\text { Ages } 0 \text { to } 4 & 23.2 & 13.9 & 6.6 & 4.5 \\ \text { Ages } 5 \text { to } 9 & 26.1 & 17.3 & 10.1 & 7.3 \\ \text { Ages } 10 \text { to } 14 & 32.6 & 25.4 & 16.4 & 12.3 \\ \text { Total ages } 0 \text { to } 14 & 26.9 & 18.3 & 10.7 & 7.8\end{array}$

D. Estimated Percent of Children Ages 0 Through 14 With a Living Absent Parent ${ }^{\mathrm{b}}$

\begin{tabular}{lrrrr} 
Ages 0 to 4 & 19.5 & 10.3 & 3.9 & 2.5 \\
Ages 5 to 9 & 14.4 & 6.3 & 1.4 & 0.9 \\
Ages 10 to 14 & 12.1 & 7.1 & 0.8 & 1.2 \\
Total ages 0 to 14 & 15.9 & 8.1 & 2.2 & 1.6 \\
\hline
\end{tabular}

${ }^{a}$ Includes children residing in group quarters

b This estimate was calculated as:

$$
\frac{(\text { Panel C) }-(\text { Panel B })}{100-\text { Panel B }}
$$

Table 3 further illuminates the findings presented in Table 2. Among white children in 1880 , parental mortality was the main reason for the absence of parents: Only about 2 percent of whites resided separately from a living mother or a living father. Despite the higher mortality of blacks, on the other hand, less than half of the percentage of children residing without both parents can be accounted for by

of their child until the time of the census. Parental ages at the births of their children were tabulated directly from the 1880 Public Use Sample for children less than age 2 residing with a parent by the race and sex of the parent. The age distribution of children of each race was also tabulated from the 1880 sample. The life tables for blacks were taken from Eblen (1974). For whites, I used a model West level 11.45 life table (Coale and Demeny 1983), a level recommended by Michael Haines for adult 


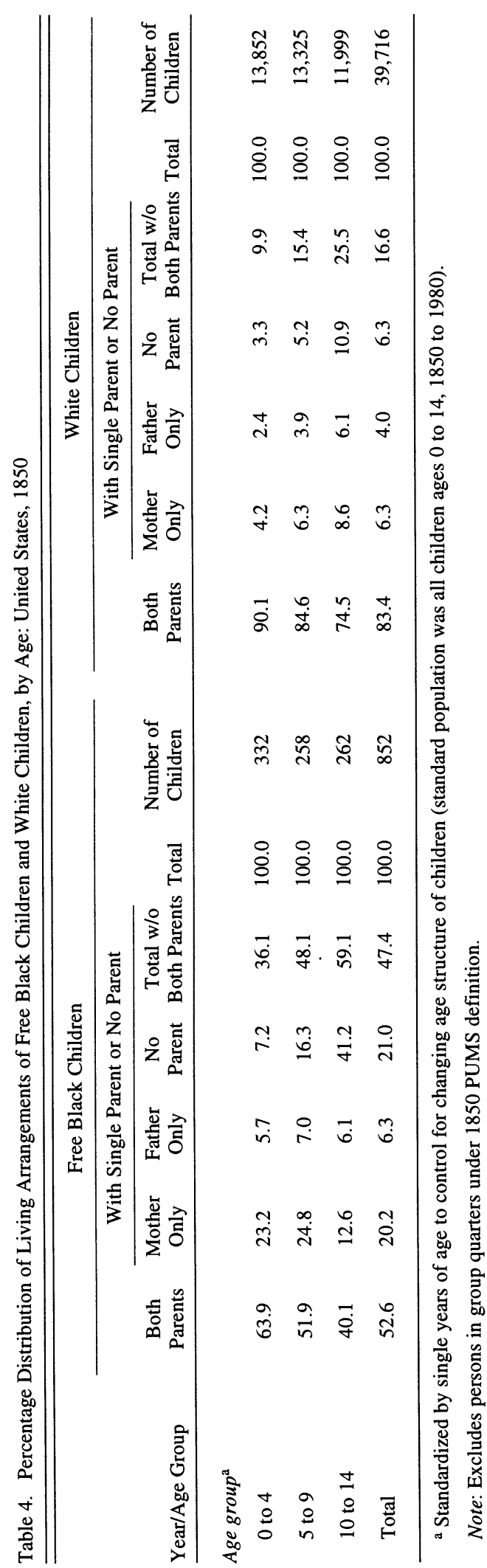

parental death. Once we controlled for the effects of mortality, parental absence was over five times more frequent among blacks than it was among whites.

The race difference in residence with parents in the late nineteenth and early twentieth centuries was most pronounced among very young children. Overall, for example, fewer than 5 percent of U.S. children under age five had a deceased father in the late nineteenth century; but among blacks, 23 percent under age five resided without a father, compared with 7 percent of whites. The large race differential among the very young suggests that the African-American pattern of residence with a single parent did not usually result from the departure or death of a parent; in most cases, only one parent was present from a very early age. Indeed, Panel D of Table 3 suggests that the percentage of absent parents among black children with surviving parents actually declined with age, although this finding may be an artifact of exaggerated black mortality. ${ }^{8}$

We can push the analysis back 30 years prior to 1880 by comparing the living arrangements of free black children to white children in a nationally representative subsample of the 1850 PUMS currently in preparation at the University of Minnesota (Menard et al. forthcoming). Unlike the more recent censuses, the 1850 enumeration did not provide explicit information about family relationships. I have therefore developed a system of rules for inferring family relationships on the basis of age, sex, surname, and sequence in the household. I tested these

mortality in the period 1870 to 1880 (personal communication, 21 Apr. 1993; cf. Haines 1979). One might assume that the effects of parental mortality could be assessed by looking at widowhood among single parents, but as Preston, Lim, and Morgan (1992) have demonstrated, the marital status variable is too unreliable in historical census data to use it for this purpose. (On the problem of distinguishing biological parents from socially-defined parents, see note 5).

8 Using data on child survival from the 1900 Census, Preston and Haines (1991) recently demonstrated that demographers have overestimated black child mortality in the late nineteenth century. If we assume that black adult mortality has been similarly overstated, the decline of parental absence with increasing age of children disappears. Lower black mortality would also imply a higher frequency of parental absence among black children with surviving parents. 
rules against the 1880 and 1910 census years so that the reliability of the inferred relationships could be evaluated. For simple family relationships, the inference procedure is highly accurate; overall, for example, the rules correctly identify 99.4 percent of explicit spouse relationships and 96.5 percent of parent-child relationships in $1880 .{ }^{9}$ The complete inference procedure is described in Menard et al. (forthcoming). Most of the parent-child relationships missed by the procedure occurred with married or widowed daughters whose surnames differed from those of their parents; this source of error does not affect analysis of the living arrangements of children under age 15 .

Table 4 reports the percentages of free black children and white children residing with each combination of parents in 1850 . The race difference in 1850 is considerably more dramatic than in later census years; overall, almost half of free black children (47.4 percent) resided without one or both parents, compared with 16.6 percent of white children. A significant part of this difference is a result of the extremely high percentage (41.2 percent) of free black children ages 10 to 14 who resided with no parent. Most of these children were apparently servants or laborers in farm households. Perhaps many parents of these children remained in slavery and were therefore not included in the enumeration. Without knowing more about how slaves were freed, we cannot directly compare the figures in Table 4 with those from subsequent census years; the reasons for parental absence among free black children in 1850 may differ greatly from the reasons for parental absence in later census years. Nevertheless, Table 4 provides dramatic evidence that the African-American pattern of residence without two parents did not begin with the abolition of slavery.

\section{EXTENDED FAMILY STRUCTURE}

As noted earlier, many investigators have suggested that the high frequency of extended

9 Table 4 excludes persons residing in group quarters under the 1850 PUMS definition instead of the 1970 Census definition used in the other tables. This is because the 1970 definition cannot be constructed for 1850 , since it depends on information about family relationships (see note 2 ). The 1850 PUMS group quarters definition is described in Menard et al. (forthcoming).
Table 5. Percentage of Households Extended and Percent Distribution of Households by Race and Residence in Primary Family of Single Parents and Parentless Children: United States, 18801980

\begin{tabular}{|c|c|c|c|}
\hline \multirow{2}{*}{$\begin{array}{l}\text { Presence of } \\
\text { Single Parent } \\
\text { or Parentless Child }\end{array}$} & \multicolumn{2}{|c|}{$\begin{array}{l}\text { Percent } \\
\text { Extended }\end{array}$} & \multirow{2}{*}{$\begin{array}{c}\begin{array}{c}\text { Distribution of } \\
\text { Households }\end{array} \\
\text { Black White }\end{array}$} \\
\hline & lack & White & \\
\hline
\end{tabular}

1880

$\begin{array}{lrrrr}\begin{array}{l}\text { No single parent or } \\ \text { parentless child present }\end{array} & 12.3 & 15.5 & 73.4 & 88.9 \\ \begin{array}{l}\text { Single mother present } \\ \text { Single father present }\end{array} & 22.0 & 31.8 & 11.3 & 5.0 \\ \text { Parentless child present } & 91.8 & 28.2 & 4.4 & 2.5 \\ & & & & \end{array}$

$\begin{array}{lllll}\text { Total, all households } \quad 22.5 \quad 19.5 & 100.0 & 100.0\end{array}$

1910

$\begin{array}{lllll}\text { No single parent or } \quad 14.2 & 16.9 & 78.2 & 92.2\end{array}$

parentless child present

$\begin{array}{lllll}\text { Single mother present } & 40.0 & 39.6 & 9.4 & 3.7\end{array}$

$\begin{array}{lllll}\text { Single father present } \quad 33.0 & 39.0 & 3.4 & 1.8\end{array}$

$\begin{array}{lllll}\text { Parentless child present } & 94.4 & 97.4 & 9.0 & 2.3\end{array}$

$\begin{array}{lllll}\text { Total, all households } \quad 24.4 & 19.9 & 100.0 & 100.0\end{array}$

1940

\begin{tabular}{|c|c|c|c|}
\hline $\begin{array}{l}\text { No single parent or } \\
\text { parentless child present }\end{array}$ & 17.7 & 15.2 & 82.3 \\
\hline Single mother present & 51.8 & 41.3 & 8.5 \\
\hline Single father present & 41.3 & 37.1 & 2.3 \\
\hline Parentless child present & 95.0 & 93.2 & 6.9 \\
\hline
\end{tabular}

1960

\begin{tabular}{|c|c|c|c|}
\hline $\begin{array}{l}\text { No single parent or } \\
\text { parentless child present }\end{array}$ & 16.1 & 10.0 & 80.2 \\
\hline Single mother present & 40.8 & 30.5 & 10.1 \\
\hline Single father present & 46.7 & 26.2 & 1.9 \\
\hline Parentless child present & 96.0 & 90.8 & 7.8 \\
\hline Total, all households & 25.4 & 11.5 & 100.0 \\
\hline
\end{tabular}

1980

$\begin{array}{lrrrr}\begin{array}{l}\text { No single parent or } \\ \text { parentless child present }\end{array} & 9.9 & 5.3 & 75.0 & 94.3 \\ \begin{array}{l}\text { Single mother present } \\ \text { Single father present }\end{array} & 21.5 & 17.3 & 17.2 & 4.3 \\ \text { Single } & 20.2 & 2.1 & 0.7 \\ \text { Parentless child present } & 96.4 & 96.5 & 5.6 & 0.7 \\ \text { Total, all households } & 17.2 & 6.6 & 100.0 & 100.0\end{array}$

Note: For number of households, see Table 1. Excludes persons in group quarters under 1970 Census definition. Extended households contain relatives beyond a married couple and their children, such as parents or siblings of the head. Single parents are persons without spouses residing with children under the age of 15 ; parentless children are persons under age 15 residing with no parents. 
households among blacks has been a means of coping with single parenthood. This hypothesis is easily tested. Table 5 compares the percentage of black extended households and white extended households, broken down according to the presence in the primary family of single parents and their children under age 15 and parentless children under age 15 . In all census years among both blacks and whites, households containing single parents or parentless children were far more likely to be extended than households without such members. The pattern is especially striking for primary families with parentless children: At least 90 percent of such households were extended in all periods. Of course, this high percentage is not surprising, since children in primary families without any parents can only reside in nuclear families if they are listed in the census as household head or spouse.

Before 1940, the presence of single parents or parentless children can account entirely for the higher percentage of extended households among blacks. Indeed, when we controlled for single parenthood and parentlessness, the percentage of extended households was significantly higher among whites than among blacks in 1880 and 1910. After 1940, black households were more likely to be extended, regardless of whether or not they contained single parents or parentless children. Even in 1980, however, the presence of single parents and parentless children explains 56 percent of the race difference in the overall percentage of extended households (cf. Tienda and Angel 1982).

Tables 1 and 5 show that the overall percentage of extended households among blacks increased steadily from 1880 through 1940, dropped slightly in 1960, and then declined steeply in 1980. Among whites, the peak percentage of extended households occurred in 1910 , and since then the percentage has fallen consistently. In no period did the percentage of extended households exceed 27 percent for blacks and 20 percent for whites.

These long-term trends in extended family structure are somewhat misleading, because over the past century the opportunities to reside in extended families have shifted dramatically. Almost 30 years ago, Levy (1965) argued that, although the extended family is often the ideal type in high mortality societies, it rarely dominates in reality. Levy pointed out that under high mortality conditions, few people can reside with elderly kin. In particular, three-generation families are necessarily rare in societies in which most people die before their grandchildren are born or very shortly thereafter (Berkner 1972, 1975; Levy 1965).

Mortality is not the only demographic influence on the frequency of multigenerational families. In the United States and Northwestern Europe, extended families that include multiple married siblings have been extremely rare for centuries (Laslett 1972; Ruggles 1987; Wall 1983). Because of this, fertility has had a critical impact on the potential frequency of multigenerational families. When the children from a large family marry, they all ordinarily reside in separate households, and only one of those households can include the elderly parents. Marriage age is also important; late marriage sharply limits the period of overlap between generations, thus reducing or eliminating the potential for multigenerational families. ${ }^{10}$ The increase in life expectancy, decline in fertility, and fall in marriage age over the last century have greatly increased the potential for multigenerational family structure. Taken together, high mortality, high fertility, and relatively late marriage in the nineteenth century meant that a very small population of elderly people was spread thinly among a much larger younger generation. Under these circumstances, the percentage of households extended by elderly relatives was necessarily small.

Accounting for the effects of these changes on the relative frequency of multigenerational households is a complicated task. Family demographers have devised numerous models to estimate the effects of historical demographic change on multigenerational family structure (Bradley and Mendels 1978; Burch 1970; Coale 1965; Glass 1966; Ruggles 1987; Wachter, Hammel, and Laslett 1978). The conflicting results of these models have stimulated lively debate, but there is no consensus on methods for controlling for the effects of demographic change (De Vos and Palloni 1989; Kertzer 1991; King 1990; Ruggles 1990 forthcoming a).

${ }^{10}$ On the relative sensitivity of coresidence to marriage age, fertility, and mortality, see Ruggles (1987) and Wachter et al. (1978). Both studies concluded that marriage age is the critical factor, but since marriage age changed modestly from the late nineteenth century to the late twentieth century, fertility and mortality were more important in that period. 
Table 6. Percentage Distribution of Living Arrangements of Elderly Individuals and Elderly Couples, by Race: United States 1880-1980

\begin{tabular}{|c|c|c|c|c|c|c|c|c|c|c|}
\hline \multirow[b]{2}{*}{ Living Arrangement } & \multicolumn{5}{|c|}{ Elderly Blacks } & \multicolumn{5}{|c|}{ Elderly Whites } \\
\hline & 1880 & 1910 & 1940 & 1960 & 1980 & 1880 & 1910 & 1940 & 1960 & 1980 \\
\hline \multicolumn{11}{|l|}{ Residing Without Relatives } \\
\hline Alone/spouse only & 17.0 & 20.2 & 25.0 & 36.9 & 51.5 & 15.7 & 20.0 & 30.7 & 53.4 & 73.8 \\
\hline $\begin{array}{l}\text { Alone/spouse and } \\
\text { nonrelatives }\end{array}$ & 14.5 & 9.8 & 10.3 & 8.2 & 6.3 & 9.8 & 7.7 & 9.1 & 5.7 & 2.1 \\
\hline \multicolumn{11}{|l|}{ Residing With Relatives } \\
\hline Total with any relative ${ }^{\mathrm{a}}$ & 68.5 & 70.1 & 64.6 & 54.8 & 42.2 & 74.5 & 72.3 & 60.2 & 40.9 & 24.1 \\
\hline With own child & 48.5 & 51.6 & 44.8 & 32.9 & 25.6 & 60.7 & 58.9 & 47.6 & 28.2 & 16.4 \\
\hline With own adult child & 35.4 & 40.4 & 39.5 & 29.8 & 22.8 & 55.6 & 55.1 & 45.3 & 26.6 & 15.5 \\
\hline With related single parent & t 12.7 & 13.7 & 9.0 & 6.5 & 4.1 & 7.1 & 5.4 & 3.3 & 1.8 & 0.9 \\
\hline $\begin{array}{l}\text { With related parentless } \\
\text { child }\end{array}$ & 18.6 & 16.4 & 10.4 & 11.9 & 6.2 & 6.6 & 3.6 & 2.0 & 1.2 & 0.5 \\
\hline $\begin{array}{l}\text { With relatives other than } \\
\text { single parents and } \\
\text { parentless children }\end{array}$ & 37.2 & 40.0 & 45.2 & 36.4 & 31.9 & 60.7 & 63.3 & 54.9 & 38.0 & 22.7 \\
\hline Total Percent & 100.0 & 100.1 & 99.9 & 99.9 & 100.0 & 100.0 & 100.0 & 100.0 & 100.0 & 100.0 \\
\hline Number of cases & 1,609 & 1,136 & 1,110 & 1,080 & 1,709 & 13,284 & 12,432 & 13,846 & 121,021 & 17,789 \\
\hline
\end{tabular}

a Subcategories of residence with relatives are not mutually exclusive.

Notes: Excludes persons in group quarters under 1970 Census definitions. Married couples treated as single observations; adult children are aged 21 or over; single parents are unmarried persons living with their own children (under age 15); parentless children are less than 15 years with no parent living in the household.

The problem can be minimized, however, by assessing extended family structure from the perspective of the elderly. The elderly are the only demographic group whose residential opportunities have remained reasonably stable over the past century. In all periods, the great majority of elderly have had the demographic possibility of residing with their children, even though only a minority of the younger generation has had the opportunity to reside with elderly parents. ${ }^{11}$

Table 6 presents several measures of the living arrangements of persons ages 65 or older from 1880 to 1980 . Elderly married couples are

\footnotetext{
${ }^{11}$ Although demographic changes have had some effects on the living arrangements of the elderly over the past century, it is easy to demonstrate that those effects are modest. The most important factor is the decline in fertility, which meant that the elderly had fewer children with whom they could reside. Offsetting this change were declines in child mortality and increases in the ages of the elderly. For general analyses of the effects of long-term demographic change on the living arrangements of the elderly, see Ruggles (forthcoming c) and Smith (1986).
}

considered to be a single observation because the living arrangements of husbands and wives were not ordinarily determined independently. These statistics present a very different picture from the one on extended household structure presented earlier.

The majority of elderly blacks and elderly whites in the nineteenth century resided with relatives, usually their adult children. Among both blacks and whites, co-residence of the elderly with kin declined throughout the twentieth century. The magnitude of change, however, was far greater among whites than among blacks. In 1880, elderly whites were more likely to reside with relatives than were elderly blacks. The difference is especially noticeable for residence with adult children: In 1880, 55 percent of elderly whites lived with adult children, compared with only 36 percent of blacks. Thus, just as young blacks more often resided without their parents than did young whites, elderly black parents more often resided without adult children.

The percentage of elderly blacks residing with relatives remained lower than that for elderly whites until 1940. After 1940, resi- 
dence with relatives declined almost twice as rapidly among whites as among blacks, so that by 1980,42 percent of elderly blacks resided with relatives, compared with only 24 percent of elderly whites. The current race differential in multigenerational living arrangements is therefore of recent origin and did not result from changes among black families, but rather from an extremely rapid change among white families. Therefore, any explanation for why blacks reside with relatives comparatively more often than whites should actually focus on the reasons for the extraordinary decline in white co-residence over the past century. That, however, is the subject of another paper (Ruggles forthcoming d; Ruggles and Goeken 1992).

The persistent race difference in family structure is not in extended family structure, but rather in single parenthood and parentlessness among children. As shown in Table 6, those are the only categories in which black coresidence exceeded that of whites before 1960 . In fact, the percentage of elderly blacks residing with relatives other than single parents and parentless children (bottom row of Table 6) was lower than that for whites until 1980. Thus, the key to understanding the origins of African-American family structure lies not with the extended family, but rather with the living arrangements of children.

\section{DISCUSSION}

First, I have confirmed the finding of recent studies that the high incidence of single parenthood and children residing without parents among blacks is not new. The pattern is clearly evident as far back as 1850 among free blacks. From 1880 through 1960, the percentage of black children with at least one absent parent was fairly stable and about two-and-one-half times greater than the percentage among whites. Recently, the percentages of both black children and white children with absent parents have risen dramatically.

Second, I have shown that although the overall percentage of extended households has been consistently higher for blacks than for whites, in the early period this was the result of single parenthood and parentlessness among children. In fact, until 1940 extended households were more common among whites than among blacks once the effects of absent parents were controlled. Moreover, when I limited the effects of demographic changes by focusing on the elderly, it was apparent that the higher percentage of extended arrangements among blacks when compared to whites is a recent phenomenon brought about by an extremely rapid decline in extended family structure among whites.

Race differences in family structure have expanded throughout the twentieth century, especially over the past three decades. But the fundamental differences in the percentage of children residing without parents began well over a century ago. The critical question remains: What is the source of this distinctive AfricanAmerican pattern of single parenthood? Recent economic changes can be invoked to explain the growing differential between black family structure and white family structure, but they cannot explain why blacks started from a higher base.

Two alternative explanations for the origins of the African-American pattern of single parenthood and parentlessness remain open. First, residence of children without both parents could have been a response to the socioeconomic conditions faced by newly-freed blacks after the Civil War and by free blacks in 1850 . Second, the pattern could simply reflect a difference in social norms between blacks and whites, which could have developed either through the experience of slavery or could have its roots in differences between European and African cultures.

Sociologists and historians have proposed a variety of economic explanations for the disruption of black families after the Civil War. The simplest and most commonly cited of these is that conditions of extreme poverty destabilized the black family. In addition, investigators have pointed to high female laborforce participation, inadequate employment opportunities for males, and narrow wage differentials between men and women as factors that may have encouraged marital instability among blacks (Morgan et al. 1983; Rolison 1992; Sanderson 1979).

Causal hypotheses such as these are difficult to test. Even for the late twentieth century, for which individual-level economic data are readily available, the effects of economic factors are difficult to measure: It is easy to show that in recent years single parenthood has been associated with poverty, but that may be largely 
because single parenthood causes poverty (Eggebeen and Lichter 1991; McLanahan 1985; P. Ruggles 1990). Assessing the economic hypotheses in the nineteenth century, when the high proportion of parental absences is first observed, is even more problematic, since few individual-level socioeconomic indicators exist.

Nevertheless, some preliminary findings from the 1880 PUMS suggest that the simplest economic interpretation of the black family pattern may be inadequate. First, literate black mothers of young children were less likely to reside with a spouse than were illiterate mothers. Second, poor local economic conditions apparently were not associated with single parenthood among blacks: In fact, there was a significant positive relationship between single parenthood and per-capita wealth by county. Thus, blacks in 1880 who faced the worst conditions-illiteracy and residence in the poorest districts - had the highest odds of residing in a two-parent family. Among whites in 1880 , by contrast, such poor conditions were associated with absent parents. Although these findings are subject to alternate interpretations, they nevertheless discourage an explanation of the nineteenth-century black family pattern strictly in terms of poverty. ${ }^{12}$

What, then, are the origins of the current pattern of African-American family structure? Economic explanations cannot be ruled out, but they have to be more subtle than the simple thesis that single parenthood resulted from eco nomic stress. To assess the effects of socioeconomic factors on the black family in the late nineteenth century, it will probably be neces-

12 Among black mothers with children under age $15,22.3$ percent of those who could read resided without a spouse, compared with 20.2 percent of those who could not read. For whites, by contrast, the comparable figures were 7.9 percent for literate mothers and 11.6 percent for illiterates. The pattern is similar for fathers. The findings on the relation ship of family structure to county per capita wealth were obtained by linking the 1880 PUMS to the county-level data file for 1880 created by the InterUniversity Consortium for Political and Social Research (1965). The positive correlation of assessed county real and personal property per capita and parental absence for black children was significant $(p<.001)$. Such a pattern could result from the differential migration of single parents to wealthy counties, but it is noteworthy that the opposite pattern obtained for whites. sary to turn to qualitative sources and local studies based on linked census listings.

All things considered, the cultural explanations appear just as persuasive as the economic ones. It is likely that there have been persistent differences between blacks and whites in norms about residence with spouses and children. Given the radical differences in their backgrounds and experiences, it would be remarkable if African-Americans and white Americans in 1880 had an identical set of family values. European norms transmitted by American masters under slavery doubtless influenced the black family, but the experience of slavery and African traditions were probably just as important.

Steven RugGles is an Associate Professor of History at the University of Minnesota and Director of the Social History Research Laboratory. His book, Prolonged Connections: The Rise of the Extended Family in Nineteenth Century England and America (University of Wisconsin, 1986) won the William J. Goode Distinguished Book Award from the Family Section of the American Sociological Association and the Allen Sharlin Memorial Award from the Social Science History Association. He is presently working on a book about changing living arrangements in the United States since the midnineteenth century; an article based on that research, entitled "The Transformation of American Family Structure," is forthcoming in the American Historical Review.

\section{REFERENCES}

Agresti, Barbara F. 1978. "The First Decades of Freedom: Black Families in a Southern County, 1870 and 1885." Journal of Marriage and the Family 40:697-715.

Allen, Walter R. 1979. "Class, Culture and Family Organization: the Effects of Class and Race on Family Structure in Urban America." Journal of Comparative Family Studies 10:301-13.

Aschenbrenner, Joyce. 1973. "Extended Families Among Black Americans." Journal of Comparative Family Studies 4:257-68.

Berkner, Lutz K. 1972. "The Stem Family and the Developmental Cycle of the Peasant Household: An Eighteenth-Century Austrian Example." American Historical Review 77:398-418.

$\rightarrow-$. 1975. "The Use and Misuse of Census Data for the Historical Analysis of Family Structure." Journal of Interdisciplinary History 4:721-38.

Bigham, Darrell E. 1981. "Family Structure of Germans and Blacks in Evansville and Vanderburgh County, Indiana, in 1880: A Comparative Study." The Old Northwest 7:255-75. 
Billingsley, Andrew. 1968. Black Families in White America. New York: Touchstone.

$\rightarrow$ Bradley, Brian and Franklin Mendels. 1978. "Can the Hypothesis of a Nuclear Family be Tested Empirically?’' Population Studies 32:381-94.

$\rightarrow$ Brewer, Rose M. 1988. "Black Women in Poverty: Some Comments on Female-Headed Families." Signs 13:331-39.

Brown, Sheri Bartlett and Daniel C. Kallgren. 1989. "The Black Family in the United States: A Reassessment." Paper presented at the annual meetings of the Social Science History Association, 18 Nov., Washington, DC.

$\rightarrow$ Burch, Thomas K. 1970. "Some Demographic Determinants of Average Household Size: An Analytic Approach.” Demography 7:61-70.

Carlson, Shirley. 1988. "Family and Household in a Black Community in Southern Illinois." International Journal of the Sociology of the Family 18:203-13.

Coale, Ansley J. 1965. "Estimates of Average Size of Household." In Aspects of the Analysis $o_{-}$ Family Structure, by M. J. Levy, A. J. Coale, L. A. Fallers, D. M. Schneider and S. S. Tomkins. Princeton, NJ: Princeton University.

Coale, Ansley J. and Paul Demeny. 1983. Regional Model Life Tables and Stable Populations. 2d ed New York: Academic.

$\rightarrow$ De Vos, Susan and Alberto Palloni. 1989. "Formal Models and Methods for the Analysis of Kinship and Household Organization." Population Indes 55:174-98.

Dubois, W. E. B. 1899. The Philadelphia Negro. Philadelphia, PA: University of Pennsylvania.

- 1909. The Negro American Family. Atlanta, GA: University Press.

$\rightarrow$ Eblen, Jack E. 1974. "New Estimates of the Vital Rates of the United States Black Population During the Nineteenth Century." Demography 11: 301-19.

$\rightarrow$ Eggebeen, David J. and Daniel T. Lichter. 1991. "Race, Family Structure and Changing Poverty Among American Children." American Sociological Review 56:801-17.

Elkins, Stanley. 1963. Slavery: A Problem in American Institutional and Intellectual Life. New York: University Library.

$\rightarrow$ Farley, Reynolds. 1971. "Family Types and Family Headship: A Comparison of Trends Amon Blacks and Whites." Journal of Human Resources. 6:275-96.

$\rightarrow$ Fischer, Ann, Joseph D. Beasley, and Carl H. Harber. 1968. "The Occurrence of the Extended Family at the Origin of the Family Procreation: A Developmental Approach to Negro Family Structure." Journal of Marriage and the Family $\rightarrow$ 30:290-300.

Frazier, E. Franklin. 1932. The Negro Family in Chicago. Chicago, IL: University of Chicago. 1939. The Negro Family in the United
States. Chicago, IL: University of Chicago.

$\rightarrow$ Furstenberg, Frank, Theodore Hershberg, and John Modell. 1975. "The Origins of the FemaleHeaded Black Family: The Impact of the Urban Experience.” Journal of Interdisciplinary History 6:211-34.

Glass, David. 1966. London Inhabitants Within the Walls 1695. Leicester, England: London Record Society.

Goeken, Ronald. 1989. "Black Extended Families in the Twentieth Century: A Quantitative Analysis of Research Models." Paper presented at the annual meeting of the Social Science History Association, 18 Nov., Washington, DC.

Gordon, Linda and Sara McLanahan. 1991. "Single Parenthood in 1900." Journal of Family History 16:97-116.

Graham, Stephen N. 1979. 1900 Public Use Sample: User's Handbook. Ann Arbor, MI: University of Michigan, Inter-University Consortium for Political and Social Research.

Gutman, Herbert, 1975. "Persistent Myths About the Afro-American Family." Journal of Interdisciplinary History 6:181-210.

- 1976. The Black Family in Slavery and Freedom. New York: Pantheon.

Haines, Michael R. 1979. "The Use of Model Life Tables to Estimate Mortality for the United States in the Late Nineteenth Century." Demography 16:289-312.

$\rightarrow$ Hays, William C. and Charles H. Mindel. 1973. "Extended Kin Relations in Black and White Families." Journal of Marriage and the Family 35:51-7.

Harris, William. 1976. "Work and the Family in Black Atlanta, 1880." Journal of Social History 10:332-40.

Hill, Robert, 1971. The Strengths of Black Families. New York: Emerson Hall.

$\rightarrow$ Hofferth, Sandra L. 1984. "Kin Networks, Race, and Family Structure." Journal of Marriage and the Family 46:791-806.

Inter-University Consortium For Political and Social Research. 1965. Historical Demographic Economic and Social Data: The United States, 1790-1970. Ann Arbor, MI: University of Michigan, Inter-University Consortium for Political and Social Research.

Kertzer, David. 1991. "Household History and Sociological Theory." Annual Review of Sociology 17:155-79.

King, Miriam L. 1990. "All in the Family? The Incompatibility and Reconciliation of Family Demography and Family History." Historical Methods 23:32-41.

Kobrin, Frances. 1976. "The Fall in Household Size and the Rise of the Primary Individual in the United States." Demography 13:127-38.

$\rightarrow$ Krech, Shepard. 1982. "Black Family Organization in the Nineteenth Century: An Ethnological Per- 
spective." Journal of Interdisciplinary History 12:429-52.

Lammermeir, Paul. 1973. "The Urban Black Family in the Nineteenth Century: A Study of Black Family Structure in the Ohio Valley, 18501880." Journal of Marriage and the Family 35:440-55.

Laslett, Peter. 1972. "Introduction: The History of the Family." Pp. 1-89 in Household and Family in Past Time, edited by P. Laslett and R. Wall. Cambridge, England: Cambridge University.

Levy, Marion J. 1965. "Aspects of the Analysis of Family Structure." In Aspects of the Analysis of Family Structure, edited by M. J. Levy. Princeton, NJ: Princeton University.

Martin, Elmer P. and Joanne M. Martin. 1978. The Black Extended Family. Chicago, IL: University of Chicago.

McAdoo, Harriet Pipes. 1980. "Black Mothers and the Extended Family Support Network." In The Black Woman, edited by L. Rogers-Rose. Beverly Hills, CA: Sage Publications.

$\rightarrow$ McLanahan, Sara. 1985. "Family Structure and the Reproduction of Poverty." American Journal of Sociology 90:873-901.

Menard, Russell R., Steven Ruggles, Lisa Dillon, Todd Gardner, Diana Magnuson, and Matt Mulcahy. Forthcoming. 1850 Public Use Sample: User's Guide. Ann Arbor, MI: University of Michigan, Inter-University Consortium for Political and Social Research.

$\rightarrow$ Morgan, S. Philip, Antonio McDaniel, Andrew T. Miller, and Samuel H. Preston. 1993. "Racial Differences in Household Structure at the Turn of the Century." American Journal of Sociology 98:798-828.

Moynihan, Daniel P. 1965. The Negro Family: The Case for National Action. Washington, DC: U.S. Government Printing Office.

Myrdal, Gunnar. 1944. An American Dilemma. New York: Public Affairs Committee.

$\rightarrow$ Nobles, Wade W. 1978. "Toward an Empirical and Theoretical Framework for Defining Black Families." Journal of Marriage and the Family 40:679-98.

Owens, Leslie Howard. 1976. The Species of Prosperity: Slave Life and Culture in the Old South. New York: Oxford University.

$\rightarrow$ Pleck, Elizabeth. 1972. "The Two-Parent Household: Black Family Structure in Late-Nineteenth Century Boston." Journal of Social History 6:331.

Preston, Samuel H. and Michael R. Haines. 1991. Fatal Years: Child Mortality in Late NineteenthCentury America. Princeton, NJ: Princeton University.

$\rightarrow$ Preston, Samuel H., Suet Lim, and S. Philip Morgan. 1992. "Misreporting of Marital Status, Marital Order and Marital Duration: African-American Women in the United States Census of
1910." Demography 29:1-15.

Rainwater, Lee and William L. Yancey. 1967. The Moynihan Report and the Politics of Controversy. Cambridge, MA: Massachusetts Institute of Technology.

Riessman, Frank. 1966. "In Defense of the Negro Family." Dissent 13:141-44.

Riley, Peter. 1975. "The Black Family in Transition: Louisiana, 1860-1865." Journal of Southern History 41:369-80.

Rolison, Garry L. 1992. "Black, Single Female Headed Family Formation in Large U.S. Cities." Sociological Quarterly 33:473-81.

Ruggles, Patricia. 1990. Drawing the Line: Alternative Poverty Measures and Their Implications for Public Policy. Washington, DC: Urban Institute.

Ruggles, Steven, 1986. "Availability of Kin and the Demography of Historical Family Structure." Historical Methods 19:93-102.

1987. Prolonged Connections: The Rise of the Extended Family in Nineteenth Century England and America. Madison, WI: University of Wisconsin.

$\rightarrow$ 1988. "The Demography of the Unrelated Individual, 1900-1950." Demography. 25:521-36.

. 1990. "Family Demography and Family History: Problems and Prospects." Historical Methods 23:22-31.

$\rightarrow-$ 1991. "Comparability of the Public-Use Data Files of the U.S. Census of Population." Social Science History 15:123-58.

. Forthcoming a. "Confessions of a Microsimulator: Problems in Modeling the Demography of Kinship." Historical Methods.

. Forthcoming b. "Historical Demography From the Census: Applications of the American Census Microdata Files." In Old and New Methods in Historical Demography, edited by R. Schofield and D. Reher. Cambridge, England: Cambridge University.

. Forthcoming c. "Living Arrangements of the Elderly in the United States." In Aging and Intergenerational Relations: Historical and Cross-Cultural Perspectives, edited by T. K. Hareven. Berlin, Germany: de Gruyter.

. Forthcoming d. "The Transformation of American Family Structure." American Historical Review.

Ruggles, Steven, Russell R. Menard, William Block, Todd Gardner, Ron Goeken, Sandra Jahn, Virginia Jelatis, Daniel Kallgren, Diana Magnuson, Matthew Sobek, Jeff Stewart, and JoAnn Winkels. 1993. 1880 Public Use Microdata Sample: United States Census of Population. Ann Arbor: University of Michigan, Inter-University Consortium for Political and Social Research.

Ruggles, Steven, Diana Magnuson, Matthew 
Sobek, J. David Hacker, Sandra Jahn, Russell R. Menard, and David Ryden. Forthcoming. Integrated Public Use Microdata Series: Preliminary Version 1. Minneapolis, MN: Social History Research Laboratory.

Ruggles, Steven and Ron Goeken. 1992. "Race anc Multigenerational Family Structure, 19001980." Pp. 15-42 in The Changing American Family: Sociological and Demographic Perspectives, edited by S. J. South and S. Tolnay. Boulder, CO: Westview Press.

$\rightarrow$ Sanderson, Warren C. 1979. "Herbert Gutman's The Black Family in Slavery and Freedom 1750 1925: A Cliometric Reconsideration." Social Science History 3:66-85.

Scanzoni, John H. 1971. The Black Family in Modern Society. Boston, MA: Allyn and Bacon.

$\rightarrow$ Shifflett, Crandall A. 1975. "The Household Composition of Rural Black Families: Louisiana County, Virginia, 1880." Journal of Interdisciplinary History 6:235-60.

Shimkin, Demitri, Edith Shimkin, and Dennis Frate. 1978. The Extended Family in Black Societies. The Hague, The Netherlands: Mouton.

Smith, Daniel S. 1986. "Accounting for Change in the Families of the Elderly in the United States, 1900-Present." Pp. 87-109 in Old Age in a Bureaucratic Society: The Elderly, The Experts, and the State in American History, edited by D. Van Tassel and P. N. Stearns. Westport, CT: Greenwood.

$\rightarrow-$. 1992. "The Meanings of Family and Household: Change and Continuity in the Mirror of the American Census." Population and Development Review 18:421-56.

Stack, Carol. 1974. All Our Kin: Strategies for Survival in a Black Community. New York: Harper and Row.

Staples, Robert. 1975. "The Black Family in Evolutionary Perspective.” Black Scholar 5:2-9.

Strong, Michael, Samuel H. Preston, Ann R. Miller, Mark Hereward, Harold R. Lentzner, Jeffrey R.
Seaman and Henry C. Williams. 1989. User's Guide: Public Use Sample, 1910 Census of Population Ann Arbor, MI: University of Michigan, Inter-University Consortium for Political and Social Research.

Tienda, Marta and Ronald Angel. 1982. "Headship and Household Composition Among Blacks, Hispanics and Other Whites." Social Forces 61:508-31.

U.S. Bureau of the Census. 1972. Public Use Samples of Basic Records From the 1970 Census: Description and Technical Documentation. Washington, DC: U.S. Government Printing Office.

1973. Technical Documentation for the 1960 Public Use Sample. Washington, DC: U.S. Government Printing Office.

_ 1982. Public Use Samples of Basic Records From the 1980 Census: Description and Technical Documentation. Washington, DC: U.S. Government Printing Office.

1983. 1980 Census of Population: Subject Reports. Persons by Family Characteristics. Washington, DC: U.S. Government Printing Office.

1984a. Census of Population, 1940: Public Use Sample Technical Documentation. Washington, DC: U.S. Government Printing Office.

. 1984b. Census of Population, 1950: Public Use Sample Technical Documentation. Washington, DC: U.S. Government Printing Office.

Wachter, Kenneth, Eugene Hammel, and Peter Laslett. 1978. Statistical Studies in Historical Social Structure. New York: Academic.

Wall, Richard. 1983. Family Forms in Historic Europe Cambridge, England: Cambridge University.

Wilson, William Julius. 1987. The Truly Disadvantaged: The Inner City, the Underclass, and Public Policy. Chicago: University of Chicago. 